\title{
Aligning Sales and Operations Management: An Agenda For Inquiry
}

\author{
Deva Rangarajan \\ Ball State University \\ Miller College of Business \\ 2000 w University Avenue, Muncie, IN 47306 \\ drangarajan@bsu.edu \\ Arun Sharma \\ University of Miami \\ School of Business Administration \\ P.O. Box 248027, Coral Gables, FL 33124-6520 \\ asharma@miami.edu \\ Bert Paesbrugghe \\ IESEG School of Management \\ 1 Parvis de La defense, 92800 Puteaux, France \\ b.paesbrugghe@ieseg.fr \\ Robert Boute \\ Vlerick Business School \\ Reep 1, Gent, 9000 Belgium \\ robert.boute@vlerick.com
}

There is a rapid growth in solution selling in practice and a commensurate increase in research in this area. The focus of this sales strategy is on providing solutions to customer problems that typically entails combining products and services from the provider firm as well as other firms. The fulfilment of these solutions requires operations management support. In spite of the need for closer collaboration between sales and operations management, more research is needed on the interface of these two functions. In order to deepen our understanding of the interface of sales and operations management, we undertook qualitative research and conducted in-depth interviews of senior executives in global firms to determine the need for sales and operations management cooperation. We followed the qualitative research with a review of extant research on the interface of sales and operations management. Finally, we conducted a survey of academic researchers to identify areas and themes of future research in this area. We summarize the implications of our findings for future research.

Keywords: Sales and Operations Management; Integration; Solution Selling; Cooperation 
In today’s hypercompetitive marketplace, sales organizations are increasingly focusing on consultative selling and solution selling. An ignored aspect of solution or consultative selling is the role of operations management in the selling process. As an example, Tuli et al. (2007, p. 5) define solutions as "a set of customer-supplier relational processes comprising (1) customer requirements definition, (2) customization and integration of goods and/or services and (3) their deployment, and (4) post deployment customer support, all of which are aimed at meeting customers' business needs." While the sales function is critical in the first two stages; the service function is critical in the fourth stage; the operations management function is critical for the second and third stages. It is clear that there is need for a deep integration of sales and operations management in solution selling and a non-involvement of operations management with sales could lead to a failure to fulfil customer needs. While there has been considerable research on the interface of sales and service (e.g., Neu and Brown 2005; Rapp et al. 2017), additional research is needed on the interface of sales and operations management. This is in the context of "portfolio of relationships" suggested by Plouffe et al. (2016), in which salespeople need to manage relationship with customers, internal business functions, and external business partners. More research is needed because firms that have tried to move to solution selling have seen little gain from it (Johansson, Krishnamurthy, Chandru, and Schlissberg 2003; Stanley and Wojcik 2005; Sharma and Iyer 2011). One of the reasons for the lack of gains may be the absence of coordination between sales and operations management. Operations management is typically focused on lean operations and efficiency and providing customized solutions for customers has not been a priority.

In general, there has been a call for enhanced cooperation between different functional areas (Gulati 2013; Kotler, Rackham, and Krishnaswamy 2006) to deliver successful customer 
solutions (Kumar 2004), but more academic research is needed. As Esper et al. (2010) suggest, integration between demand and supply is regarded as necessary, but seldom achieved.

In this paper, we focus on the collaboration between sales and operations management from a broad perspective. In this regard, we attempt to determine the interaction between sales and operations management, and take a three-pronged research approach - managerial perspectives, examining extant research, and collecting data from researchers on what areas would enhance their understanding of the interaction. This multi-method perspective allows us to better understand and identify gaps, which when addressed will enhance our understanding of the sales and operations management area.

To achieve these objectives, we first conducted a qualitative research study by undertaking in-depth interviews with senior executives in ten firms. We wanted to determine the need for sales and operations management collaboration and to identify some key drivers of successful cross-functional relationships. Following the qualitative research, we conducted a review of extant research on the interface between sales and operations management and found limited research. Then, we conducted a survey of academic researchers in the area to identify areas and themes of future research in this area, followed by a second qualitative study of managers from an additional ten firms.

In examining the research gaps, we found that managerial issues such as the creation of an interface department, salespeople getting overall customer satisfaction targets, and organizational culture issues such as job rotations, special organizational programs to promote collaboration and joint training programs have not been addressed in the current literature. We also found that academics suggest further research in the areas of technology/sales force automation, intra-organizational issues, forecasting, sales evaluation and performance, and 
sales/marketing strategy.

The layout of the paper is as follows. We start the paper by examining the critical need for inter-functional coordination and sales and operations management coordination, and highlight the consequences if this is not achieved. We then report on a qualitative research in which we interviewed senior executives from ten firms to understand the practitioner's view of the coordination of sales and operations management. We then report on the results of a literature review in the area of marketing and operations management. This is followed by a section based on a survey of academics who identify areas for future research and suggest possible research questions, and a follow-up qualitative study. We conclude with a summary of our findings and implications for research and practice.

\section{NEED FOR COOPERATION BETWEEN SALES AND OPERATIONS MANAGEMENT}

Before we discuss the need for cooperation between sales and operations management, we need to describe the research on inter-functional coordination. As organizations grow, main organizational goal and hence the organizational strategy is implemented through different functional areas like marketing, sales, research and development (R\&D), supply chain (Miller and Arnold 1998) and vertical specialization starts to dominate the mindset of the people within the different departments (Cilliers and Greyvenstein 2012). Organizational silos can be observed between various functions and have been an important part of research. For example, the relationship between the marketing function and other areas has been extensively studied in the context of group and organizational identity (e.g., Randel 2002; Gupta and Ogden 2009; Grier and Deshpandé 2001).

Homburg and Jensen (1997) examined research articles on the relationship between the 
marketing department and other departments, such as: sales; R\&D; finance; manufacturing; quality management; engineering; human resources; and Information Technology (IT). The authors suggest that the main reason of conflict between internal business relationships is due to their differing department goals. Marketing is categorized by a long-term orientation and is more product orientated, while, for example, sales is considered more short-term and customer oriented.

Likewise, Nauta, De Dreu, and Van der Vaart (2000) found similar goal incompatibilities that ensues the operations and the planning department, where operations usually focuses on high quality and efficient production, the planning department generally concentrates on the speed of delivery and on-time deliveries. Similarly, research by Shapiro (1977) examined the chronical conflict between the manufacturing-related departments, or the back-offices, and the front offices, such as the sales department. Back-office departments have a cost-reduction goal by striving to the highest levels of efficiency within the production process, while the goal of front office departments is to increase revenues by being customer centric.

This organizational silo problem is also embedded in the organizational behavior literature (Greenberg and Baron 1995). Prior research on organizational silos shows that organizational silos lead to a dysfunctional organization. Moreover, Diamond and Allcor (2009) found that silo mentality strongly influences work behavior, and the disconnection between the employee and the other departments. Brewer and Kramer (1986) found that, based on social identity theory, employees favor their own department and, to a certain extent reject other departments. Thompson and Loewenstein (1992) find that employees overestimate the contributions of their own department, and undervalue those of other departments.

The most common suggestion by researchers to solve this coordination problem is to 
develop a better alignment between different internal business functions (Dahler-Larsen 1998). Other propositions by researchers to tackle this issue are management by objectives (St. John 1991); soft human resource management (Beer et al. 1984); and the implementation of a processoriented organizational layout (e.g., Christopher 1998).

Sales and operations management collaboration informs the operations of a firm in order to better adjust demand and supply. The literature in the area has consistently highlighted the critical role of sales and operations management collaboration for the success of the organization (Laanti, Garbrielsson, and Gabrielsson 2007; Storbacka 2011; Ivert et al. 2015). In addition, Swaim, Maloni, Bower, and Mello (2016) suggest that an enhanced alignment between the sales and operations functions leads to an increase in control and agility of businesses and is an important asset in the emerging era of enhanced competition. They also find that sales and operations engagement is positively correlated to higher operational, market, and profitability outcomes.

The success of sales and operations management integration depends on how well the sales and operations culture is embedded across all functions and levels within a company (Lapide 2002). Despite the effort it takes to fruitfully implement and manage sales and operations management (Grimson and Pyke 2007), the advantages of properly integrating sales and operations management can be numerous. That may be the reason that Grimson and Pyke (2007) suggest that the explicit goal of sales and operation management alignment should be to maximize profit.

The research quoted in previous paragraphs highlights the critical need for enhancing the collaboration between sales and operations management. A quick review of the literature on this topic indicates that research is still lacking in this domain (Malhotra and Sharma 2002) and that 
more research is needed (Pagell 2004). Plouffe et al. (2016) have also suggested further research in this area. In the following sections, we highlight the findings of a qualitative study, an indepth literature review, and a survey of academics we undertook to further explore this area.

\section{QUALITATIVE RESEARCH STUDY}

To understand the importance of collaboration between sales and operation management, we undertook a qualitative study. The qualitative study was based on the case study approach suggested by Eisenhardt (1989). Based on grounded theory (Glaser and Strauss 1967, Yin 2013), Eisenhardt (1989) proposes a method of using case studies to contribute to theory building by using techniques such as triangulation by multiple investigators, cross-case analyses, and existing literature.

We conducted extensive in-depth interviews with senior executives from ten firms that were predominantly operating in the business-to-business domain (please see Table 1 for sample details). Two of the ten firms also had a business-to-consumer division. To enhance our focus, we requested the participants to focus on the business-to-business aspects in the interviews. We were interested in understanding why the collaboration between sales and operations management was important and how these firms were currently managing the collaboration. This was in keeping with Eisenhardt (1989) who suggests case study research to be based on certain a priori specified constructs. In keeping with the requirements of case study research (Eisenhardt 1989), we chose a theoretical sampling method to account for differences between product/service dominant companies, regional/global companies, sales/operational executives. Additionally, to ensure triangulation by multiple investigators, we had the principal sales investigator talk to operational executives and a principal supply chain investigator conduct the 
interviews with the sales executives.

\section{Insert Table 1 about here}

A sample of eleven participants were contacted based on their relationship with the coauthors and all eleven agreed to participate in the research. All the participants were male and had greater than 15 years of work experience. While six of the eleven participants had a global role, five had either a European role or more of a regional role. Five of the eleven participants had experience in different functions within their organization. All participants worked in specific business units within the multinational firms, but all the participants were familiar with how other business units within their companies worked on aligning sales and operations management.

We conducted semi-structured, in-depth interviews with the participants that lasted between 60 and 75 minutes. Except for two of the interviews that were conducted over Skype, all the other interviews were face-to-face either at the participant's office or at the offices of the authors. Six of the eleven interviews were conducted by one author and the remaining five by one the other authors. The participants were asked to elaborate on four open-ended questions: (a) "How important is the collaboration between sales and operations management?”; (b) "How does their company align the sales and operations management functions?”; (c) “Can you provide concrete examples of specific actions taken to achieve alignment?"; and (d) "What were the outcomes of the specific actions taken to align sales and operations management?”. Based on their responses participants were probed for additional information to provide more clarity on the information that they provided. We were also asked not to mention the names of the companies in our report. 
Due to the sensitive nature of the information provided, all the participants insisted on non-disclosure agreements and did not want the interviews to be recorded and so field notes were taken (Bernard 2012). While we did not formally manage and code the field notes to ensure the trustworthiness of the findings from our interviews, we used the criteria suggested by Lincoln and Guba (1985). As mentioned earlier, both the interviewers (who each had their own theoretical based on their field of specialization- sales and supply chain management) met after each interview to compare notes and adapt the questions wherever necessary for subsequent interviews. To ensure triangulation of our findings, we had one of the co-authors not involved in the research process go over our findings.

\section{QUALITATIVE INTERVIEW RESULTS}

The first issue that we addressed was the importance of alignment between sales and operations management functions in an organization. There was unanimous agreement that an alignment between sales and operations management was critical. For example, Firm $\mathrm{H}$ had undergone a major organizational restructuring. Being a waste management company, the firm's processes and systems were run by the operations department. However, during the economic crisis, the company had started to shift its focus to become a more commercially oriented, customer-centric organization. However, facing increased price pressure from customers, increased competition, and increased costs associated with service delivery (and failures), top management issued a directive to decrease costs associated with inventory management, which could only be undertaken if there was close collaboration between sales and operations functions. The company succeeded in aligning sales and operations management, which lead to higher sales and profitability. 
Most companies we interviewed had found themselves in a similar position as Firm H. They found that a lack of collaboration between sales and operations management negatively affected revenues and profitability. The firms stated that a lack of a company specific alignment process between sales and operations management not only had a direct impact on the financial performance of a firm, but also on the long-term viability of the firms.

As mentioned earlier, we were interested in identifying business practices that companies deployed to align sales and operations management functions. It became clear after the first three interviews that different firms had different practices in place to align sales and operations management, and of keeping track of the efficacies of these practices. We identified five practices that were mentioned by more than half of the participants - other functional team involvement; collaborative environment: internally and externally; goal alignment; organizational culture; and, top management involvement to be critical elements in the success of effective collaboration between sales and operations management. While not all firms utilized all elements of best practices, we identified certain common practices across all the firms. These practices are listed in ascending order of how many times they were mentioned by the participants.

Other Functional Team Involvement. Our interviewees suggested that for sales and operation management alignment, the process needs to include other functional teams as well, such as finance, procurement, and IT. Firm E stated that one of the key changes that enabled their progress to climb the sales and operation management maturity ladder was to understand and process vast amounts of data that was available at the firm. Although the sales and operation management teams were trying to measure the same outcomes, the different data metrics across 
the different functions became a hurdle during collaboration efforts. The reconciliation process began by holding a series of high-level meetings region by region, involving sales, supply and product management, with the purpose of defining a forecast per product group. Through a process of data and trend analysis, order book comparison, and taking into account roll out schedules - a consensus demand volume was reached and then translated into a consensus forecast for all departments. The forecast was evaluated by the planning team as well as the purchasing team who analyzed the plan with special attention to productivity constraints and potential shortages, making a plan to mitigate potential risks related to critical suppliers or components.

Firm A involved finance in the second stage of their sales and operation management process to aide in realistic financial budgeting and forecasting. They also required that the finance department assist in the forecasting of promotional products whereas historically, forecasting was only for standard products. Firm A also mentioned that IT involvement was crucial as the sales and operation management process relied heavily on tools such as Vendor Managed Inventory (VMI) and Collaborative Planning, Forecasting and Replenishment (CPFR) with their main customers.

Firm $\mathrm{H}$ created eight new business finance controllers located within the specific regions. The finance controllers reported to headquarters, however; the majority of their work (approximately 80-90\%) was done with the regional sales and operation management teams. Firm H stated that this change had helped deliver greater operational efficiency through analyses including activity-based costing, improved payment terms, and negotiating prices.

Firm I, to align the different perspectives and to mitigate conflict, created an "interface department”. Being in a highly capital-intensive business and at the same time oriented towards 
customer intimacy, the necessity for a department that contributed to production planning and was able to provide the sales team with the most accurate information on areas such as lead times and quality levels was of paramount importance. The “interface department” acted as the knowledge center with responsibility for the cost model and for judging which products were the most appealing, both in terms of margins and technical fit to production facilities.

\section{Collaborative Environment: Internally (Sales and Operations Management) and}

Externally. Our respondents stressed that firms must set up the right structure to implement a collaborative environment where the internal teams communicate, align, and share knowledge/experience to guarantee success of the sales and operation management processes. The companies also commented that once internal collaboration is achieved (amongst the sales and operations management teams), the principles should be extended externally, i.e., by collaboration with the customers.

Firm J decided to establish a biweekly, sales-lead meeting. The first purpose of the meeting was to discuss upcoming deals/projects, and which projects were to be the operational priorities. The second purpose was to raise awareness of the potential changes in the regulatory environment and other constraints that could directly impact the sales environment. The meeting was mandatory for sales and operations management departments to ensure the necessary level of support for effective execution.

Firm F was able to promote both internal and external collaboration between the sales and operations teams on one side and the customer on the other. The company introduced 'an annual voice of customer’ exercise, which brought all three groups together (sales, operations management, and the customer). From an internal collaboration perspective, the meeting allowed 
sales and operations to act as a single entity in front of the customer. From an external collaboration perspective, the customer and the company came together to discuss issues and resolutions that affected them. Firm $\mathrm{F}$ also asked sales and operations teams work together to formulate logistic agreements with the clients. Firm F found that this collaborative effort contributed to high levels of conflict resolution within internal functions and led to an increase in customer satisfaction.

Firm C, which had more than 1,000 salespeople and key account managers, had operations management teams visiting customers monthly to understand any emerging issues and to help designing solutions to address these issues. This monthly meeting allowed operations to meet with customers that enhanced collaboration not only with the external customer but also with the internal sales team.

Firm G’s products typically were made-to-order, making it important to analyze historical sales data and merge those results with customer forecasts. Firm G had to address the bullwhip effect (Lee, Padmanabhan, and Whang 1997), referring to the increased oscillations in demand upstream in the supply chain. As the production of the firm had historically been sold out and customers could not receive the desired volumes, they over-ordered leading to a forecast accuracy of only 50\%. Looking for a solution, the company decided to have sales and operations collaborate more closely with their customers and incentivize them to provide accurate forecasts. This led to decreased inventory costs, better margins, and higher customer satisfaction levels.

Goal Alignment. Most of the executives we interviewed discussed the importance of aligning the goals of both the sales and the operations team. Again, each company tailored the goal alignment to fit their specific organization needs, but goals for all firms were to ensure each team 
was working towards the same common goal of optimizing efficiency to ensure maximum profit. The companies achieved goal alignment between the departments through common Key Performance Indicators (KPIs) and bonus schemes.

For example, Firm G redesigned the employee bonus scheme for sales and operations department to be fully aligned with the success of the overall business. Specifically, $50 \%$ of the KPIs for both sales and operations teams were related to sales volumes and other measures of overall market success, and the remaining 50\% were department-specific KPIs related to efficiency, costs, etc. Firm $\mathrm{G}$ also reported that logistics and packaging managers now cooperate with sales to deliver the right packaging, improve yield for the customers, and communicate other projects amongst the teams to raise their internal capabilities and directly influence customer satisfaction.

Firm C restructured their divisions so that the division presidents were now responsible for the entire profit and loss statement to align goals across departments. The company also stated that their global key account managers were now responsible for product sales and service levels as well as the overall Net Promoter Score (NPS) (Reichheld 2003), the common metric of success across the different departments.

Firm D had also moved towards common KPIs. Historically, the external sales force was evaluated on sales KPIs (e.g., revenue or volume), which had resulted in the sales force demanding universal product availability. Now both sales and operations are evaluated based on overall company margin, with particular attention to operational costs. Subsequently at Firm D, the internal sales team takes the initiative to interact more frequently with customers to develop a better understanding of the demand forecasts.

The above examples were not the only common KPIs mentioned by the interviewed 
companies. At Firm A, the sales and operations management teams focus on forecast accuracy from their external customers to reduce days of inventory. They have monthly or weekly meetings to discuss forecast updates. For Firm B forecast accuracy and managing stock levels had become KPIs. Finally, Firm E had a common KPI for forecast accuracy for both sales and operations management. They evaluated both teams on a common metric- 'on time in full' (OTIF), inventory turns, lead times, and total inventory levels.

Organizational Culture. Our interviews suggested that it is important that all employees understand the alignment processes, are able to impact it, and that their efforts are valued and rewarded. To ensure that employees have this knowledge and the right capabilities, many companies in our research cited the importance of their company culture as a key success factor for better sales and operations management alignment.

The majority of participants we interviewed described the importance of each functional department understanding each other's processes and goals. Many companies suggested that their organizational culture encouraged cross-functional knowledge sharing through either job rotations or special assignments. For example, at Firm G, the operations employees were encouraged to take technical support functions jobs. Since the employees experienced the goals and principles of other functions, both sales and operations management were able to better work together for the common good of the customer and the company.

Firm C also promoted job rotations within different functions. Regarding sales and operation management alignment process, job rotations on both the product, service, and the sales function were a requisite for a successful career at Firm C. In addition, annually, employees who showed high potential were asked to work on a special assignment within a different 
function. Through these programs, Firm C had seen a drastic improvement in the willingness of employees to work together.

Firm D saw that a recent change in the structure of their training programs had been responsible for improved cooperation amongst their sales and operation management teams. The company saw the need for greater cooperation and understanding between the departments. Therefore, they decided to not only require departments to take common training programs simultaneously, which led to enhanced profitability.

Top Management Involvement. The interviewed managers described how top management involvement improved sales and operation management alignment processes. Every enhanced interaction strategy aimed at better integrating sales and operations functions tended to require structural changes as well as capital investments (e.g., IT, training, KPIs, incentives), which required top management support.

Firm E executives hold a yearly sales and operation management meeting to present the finalized 12-month forecast plan to management. After this meeting, the plan is communicated in a top-down approach where the department heads informs each region of the plan. Firm C had traditionally a separate production division and a separate selling division. One unified division was created in which top management were responsible for the profit and loss of the combined division, leading to enhanced overall financial health.

In summary, the qualitative research highlighted the importance of collaboration between sales and operations management and the research identified five practices and sixteen processes that are critical elements in the success of effective collaboration between sales and operations management. These are other functional team involvement (finance; product management; too 
much data available; need for business analytics; difficulty in common KPI setting; and creation of interface department); collaborative environment - internally and externally (mandatory crossfunctional meetings; joint meeting- sales/operation/customers; increased client engagement to unite sales and operations management; and, client incentives to unite sales and operations); goal alignment (sales and operations outcomes aligned with overall business; top management KPI alignment; salespeople getting overall customer satisfaction targets; sales/operation responsible for accurate forecasting); organizational culture (job rotations; special organizational programs to promote collaboration; joint training programs); and, top management involvement (organizational structure change).

\section{LITERATURE REVIEW}

The second part of our research was determining the extant literature at the intersection of sales and operations management. We surveyed the extant literature that embodies the configuration and alignment of the sales function and the operations management function as follows. Based on the methodology by Higgins and Green (2011), we first explored the literature by searching for the following keywords in the Web of Science database: sales and operations alignment; sales and operation management alignment; sales and operation integration; sales operations; and operations selling. There are a number of articles that discuss the relationship but not the configuration of the broader marketing function with the operations/manufacturing function (e.g., Cron, Baldauf, Leigh, and Grossenbacher 2014); methodology issues when examining the cross-functional relationships (e.g., Frankel and Mollenkopf 2015); or the impact of cross-functional integration on the organizational level (e.g., Enz and Lambert 2015; Swink and Schoenherr 2015). However, most of these articles focus on sales as a function of turnover 
levels, rather than the actual sales function. In this research, we focused on the specific context of integrating both functions that foster the sales function, rather than improving operations planning.

In order to identify the extant cross-functional research from 1980 to 2017, we examined articles that were published in different literature streams. The journals in our sample are either rooted in the marketing and/or sales domains (e.g., Journal of Marketing, the Journal of the Academy of Marketing Science, Industrial Marketing Management, and Journal of Business and Industrial Marketing); or embedded in the operations management research field (e.g., Journal of Business Logistics, Journal of Supply Chain Management, Production and Operations Management, The International Journal of Logistics Management, Journal of Operations Management, International Journal of Production Economics, International Journal of Physical Distribution and Logistics Management, and International Journal of Forecasting); or in the broader general management area (e.g., Management Science, Decision Sciences, Business Horizons, Industrial Management and Data Systems).

This search yielded a total of thirty-four research articles that focused on the interaction between the sales and operations management functions. The coding of the research articles was conducted by a researcher who was "blind" to the hypotheses of the research project, and who used a set of five different coding variables that embody the scope of the research project. The variables that were used are: (1) type of research (either conceptual or empirical); (2) nature of the data set; (3) functional needs (sales and/or operations management) that were addressed; (4) key findings; and (5) discussion on the integration of operations and sales function. Based on this review, a total of thirty-four articles were identified, of which twenty-one articles were based on empirical/qualitative case study based research and thirteen were conceptual in nature. Table 2 
presents an overview of the research that discuss the integration of sales and operations management functions.

\section{Insert Table 2 about here}

Of the empirical/case study based research articles, seven papers used data from the sales function, two articles collected data from the operations management function, and twelve articles collected data from both functions (i.e., the sales-operations management dyad). Some of the key articles are discussed next.

Zarpelon Neto, Pereira, and Borchardt (2015) collected data from the sales function to specifically address the needs of the operations management function. In their work, the researchers examine possible issues in servicing customers worldwide and, in this context, they find that six different managerial challenges arise when aligning functional areas internally. These are: (1) regulations that create advantages for the local service company; (2) operational problems that stem from employee turnover and the distance that needs to be covered between clients, the factory, and the structure that supports the service provision; (3) the manufacturer culture (goods versus services-dominant logic); (4) commercial approaches (a closed relationship between the manufacturer and the customer that does not support unforeseen situations, lack of an understanding about the long-term profitability of each client, the issues that arise when contracts are inflexible, and when sales teams have to sell products and services at the same time); (5) poor manufacturer knowledge of customer needs and values (how this knowledge should be obtained, spread, and used).

Of the twelve articles that collected data from both sales and operations management functions, we identified ten papers that address both the needs of the operations and the sales function. We briefly summarize these articles. Ivert et al. (2015) used case study research 
(examined eight companies from the food industry), and discuss the integration of sales and operations subject to the planning environment. The researchers present a set of eventualities linked to supply that need to be incorporated into the sales and operation management setup and process. These contingencies are the uncertainty related to demand and supply, the effect of many product introductions, and the complexity of the production system.

Laanti, Gabrielsson, and Gabrielsson (2007) examine global companies in the wireless technology sector and identify that "born global" firms are different from companies with traditional internalization processes. A key result of their research is that these "born globals" were faster in setting up local sales and marketing branches. The main explanation for this result is the nature of the sales offering of this case; a digital service and software that can be easily distributed online. Yet, the alignment between operations and sales is not discussed in this article.

O’Leary-Kelly and Flores (2002) discuss the interconnected decisions between the sales function and manufacturing/operations function. The authors identify business models and demand uncertainty as two moderating effects on the path between the five dimensions of business success product innovation, cost leadership, superior quality, on-time delivery, product breadth, perceived demand uncertainty), and the integration of sales and manufacturing. The direction of the relationship differed depending on the type of decision that was examined (marketing/sales-based or manufacturing-based) and the type of respondent that measured the integration (marketing/sales versus manufacturing respondent). Their results show that the marketing/sales-based decisions have a positive moderating effect on the relationship between business success and the integration of sales and manufacturing, whereas the manufacturingbased decisions have a negative moderating effect. The suggested rationale is that 
marketing/sales-based choices usually serve as a basis for manufacturing-based operational decisions.

Based on case study research, Oliva and Watson (2011), examine the cross-functional conflicts in supply chain planning. The authors propose that two constructs, alignment and constructive engagement, mediate the performance of implemented planning processes. In their case study, they identified that forecasts made by the sales force for other functions usually contained many flaws because of the lack of quality related to the shared information, the procedure used, the alignment, or the little engagement between the two functions.

Storbacka (2011) depicts twelve categories that cover sixty-four capabilities and management practices related to the effective management of solution businesses. The construction of the twelve categories is based on four steps of the solution process (develop solutions, create demand, sell solution, and deliver solution) combined with three clusters of cross-functionality (commercialization, industrialization, and solution platform). An effective business model that is based on solutions requires a sophisticated synchronization of resources and business processes amongst all functions. The presented framework in the paper depicts that firms need to focus more on the multi-faceted interfaces between the commercial and the industrial side of the company. Solutions businesses are in essence cross-functional, which requires the outline of new boundary spanning roles, within and between firm functions.

Swaim, Maloni, Bower, and Mello (2016) suggest that a better alignment of the sales and operations function leads to an increased control and agility of the business. They also find that organizational sales and operations management engagement is positively related to higher operational, market, and profitability outcomes.

Turkulainen et al. (2013) explore the use of integration mechanisms (vertical, lateral formal, 
or lateral informal) in one case study, and the researchers indicate how these mechanisms vary over different project phases (project sales or project execution phase) due to contextual factors.

Wagner et al. (2014) depict a maturity model on how well the sales and operations functions are integrated. This model evaluates the internal sales and operation management process and aims to improve the organizational alignment. The sales and operations management maturity model consist of six levels (undeveloped, rudimentary, reactive, consistent, integrated, and proactive) and four dimensions (process effectiveness, process efficiency, people and organization, and information technology). The key result of this maturity model is that higher levels of sales and operations management maturity increase the sophistication of sales and operations management integration.

Finally, Feng et al. (2008) discuss how sales and operations management results in a better financial performance when it is grounded in the supply chain, than when sales and operations management is founded on a sales/production-based sales and operations management relation.

The last two articles of the twelve articles that sample both sales and operations management functions, only address the needs of one function. First, Engelseth and Felzensztein (2012) collected data from sales and operations management functions, and address the needs of the sales function. Their research suggests that business relationships are vital for linking and coordination between the two functions. Second, in the case study on contract decisions by Feng et al. (2013), the research sampled both sales and operations management executives, and incorporated the needs of the salespeople to better coordinate the supply chain regarding maketo-order manufacturing.

The themes that arise from the literature are:

1. Collaboration between sales and operations management is critical for the success of 
firms (Ivert et al. 2015; Laanti, Garbrielsson, and Gabrielsson 2007; Storbacka 2011;

Engelseth and Felzensztein 2012).

2. Enhanced sales and operations management collaboration can reduce negative sales and operations management effects (Oliva and Watson 2011; O’Leary-Kelly and Flores 2002).

3. Greater sales and operations management collaboration can improve positive sales and operations management effects (O’Leary-Kelly and Flores 2002; Swaim, Maloni, Bower, and Mello 2016; Feng, D’Amours, and Beauregard 2008; Feng et al. 2008).

\section{SURVEY OF ACADEMIC RESEARCHERS}

An area that we wanted to further explore was the direction for future research. The ideal respondents for this task are researchers active in the business-to-business and sales domains. We exactly followed the research design of Paesbrugghe et al. (2018). Given the broad research areas that could possibly be identified, we use a categorization that would help us better address topics for future research (Paesbrugghe et al. 2018). We used the standard twenty categories of sales and sales management research suggested by Plouffe, Williams, and Wachner (2008).

In order to identify the research topics, we used the survey designed by Paesbrugghe et al. (2018) to test what topics categories proposed by Plouffe, Williams, and Wachner (2008) are important for understanding collaboration between sales and operations management and to identify research questions linked to the particular research topic.

We used a self-administered online questionnaire designed by Paesbrugghe et al. (2018) and used their sample of marketing and sales researchers who were on editorial review boards of Journal of Personal Selling and Sales Management and Industrial Marketing Management. The 
link to the online questionnaire was sent to 440 researchers (email addresses were developed through public sources) with a reminder after one week. After two weeks, we got responses from 16 academics who mentioned that they were not active in this area of research and so opted out of the survey. We checked the list for duplicate email addresses, since it is possible to be a member of both review boards. In addition to initial requests, after seven months, we decided to reach out to those academics who had not filled out the survey. In total, we received 52 usable responses (32 completed questionnaires in the first two rounds and 20 completed questionnaires in the third round). In analyzing the data from the first set of response and the second set, the top five areas of study remained the same.

As stated earlier, we used the questionnaire designed by Paesbrugghe et al. (2018) to determine the importance of examining the importance of topics within categories suggested by Plouffe, Williams, and Wachner (2008). Similar to Paesbrugghe et al. (2018), we used the same questions for all the twenty research topics. For each category, the category description and topic definition were provided. As an example, for selling process and technique the following data was provided: Category Topic: Selling process and technique (e.g., intelligence; personality; knowledge structure characteristics and content; selling technique interaction strategies); Topic Definition: Individual-level approaches to improving the effectiveness of customer and prospect interactions and sales outcomes.

Similar to Paesbrugghe et al. (2018), for category 1, the question was: "We would like your opinion on the importance of studying the following topic when examining the intersection of personal selling and sales management and operations management. Please rate from 1 to 7 (1 $=$ not important and 7 = very important)", which was followed by the category topic and definition. In addition, we also asked "If you think the topic selling process and technique is 
important, can you please share a possible research question?” We asked these questions for all 20 categories. We calculated the importance for each topic and the five most important topics and their means are: technology/sales force automation (5.83); forecasting (5.50); sales evaluation and performance (5.43); intra-organizational issues (5.40); and sales/marketing strategy (5.19). These were the only areas with a mean above 5.

\section{SUMMARY OF RESEARCH FINDINGS}

To summarize research in this area and avenues for future research, we review the three research approaches. We first use the qualitative study as a base and determine if the factors were addressed in the literature survey or in the survey of academics and the results are presented in Table 3.

\section{Insert Table 3 about here}

Of the sixteen sub topics suggested by our qualitative research, we found that eleven were examined in research or highlighted by academic researchers. We regard this to be a check on the validity of our results. However, we identified five areas that were not discussed in literature or academic survey - creation of interface department to deal with better sales and operations management, sales people getting overall customer satisfaction targets to force them to work better with their operations management counterparts, organizational culture issues such as job rotations, special organizational programs to promote collaboration, joint training programs, and finally top management involvement to align sales and operations management better.

Second, we examine the top five areas for research identified by academic researchers (technology/sales force automation, forecasting, sales evaluation and performance, intra- 
organizational issues, and sales/marketing strategy) and map them to our findings from the qualitative study and the literature survey (see Table 4). We found that all of the topic areas were addressed by literature survey (although in most topics we only found a handful of studies, suggesting room for further research) but one area was not addressed by practitioners technology/sales force management.

\section{Insert Table 4 about here}

\section{Areas for Future Research}

We focus on the five areas identified by sales researchers and highlight areas for future research. In examining the issues of sales and operations alignment, research can address the issues at three levels - organizational level that encapsulates cross-functional alignment strategies; the sales organization level that primarily focuses on the management of salespeople; and, at the individual salesperson level. Although broadly classified, the research does overlap. As an example, in examining the impact of firm-level technology on alignment, there will be implications at the sales management and salesperson level. Our conceptual view of the overlapping research is presented in Figure 1. We have two areas at two levels - firm level (intra-organizational issues, and sales/marketing strategy) and sales management-level (technology/sales force automation; sales evaluation and performance); and, one area at the salesperson-level (forecasting). In addition, to enhance validity, we conducted a second qualitative study that is described next.

\section{Insert Figure 1 about here}

Qualitative Research Follow-up. In order to confirm that the gaps that we identified through our research is relevant to practitioners, we conducted additional in-depth interviews with executives/practitioners. We reached out to our contacts from the first round of interviews; 
however, none of the original set of people we interviewed were available to give us their feedback on our list of research gaps. The reasons were: unable to contact executives through email because they had switched jobs, retired or laid off by their firms; or, did not have the time to talk (over half of the original sample). Consequently, we reached out to a new sample and were able to conduct 11 interviews from 10 companies (See Table 1). We used the same methodology as in our earlier qualitative study, to identify companies from different sectors and executives from different functions. The interviews were conducted in the same manner as in the first study. We used the method suggested by Lincoln and Guba (1985).

Since we were dealing with a different set of companies than in our earlier study, we checked to see if the findings from the first study were relevant to the second group as well. A quick review of the results by an independent coder identified that the findings from both the qualitative studies were identical, except for some new practices, which were more in line with the research gaps identified based on the academic survey. In the following section, we discuss the gaps that were identified in our research and based on further multi-disciplinary research, we identify areas for future research.

We discuss the five areas of future research as identified by sales researchers in more depth in the next sections. There are at the firm level (intra-organizational issues, and sales/marketing strategy); at the sales management-level (technology/sales force automation; sales evaluation and performance); and, at the salesperson-level (forecasting).

Intra-organizational issues. In the academic field, our research yielded a number of studies that focused on the domain of sales and operations management collaboration (Engelseth and Felzensztein 2012; Chen, Lai, and Xiao 2015; Feng, D’Amours, and Beauregard 2008; Ferrel, 
Ingram, LaForge 2000; Grimson and Pyke 2007; O’Leary-Kelly and Flores 2002; Oliva and Watson 2011; Randall, Netessine, and Rudi 2006; Sheth and Sharma 2006; Soler and Tanguy 1998; Storbacka 2011; Swaim et al. 2016; Toon et al. 2016; Wagner, Ullrich, and Transchel 2014; Wilson, Boström, and Lundin 1999; Zackariasson and Wilson 2004; Zarpelon Neto, Pereira, and Borchardt 2015), but most of these research were qualitative in nature, thereby indicating the need for more quantitative research on this topic. One of the research questions raised by academics was about the ability of salespeople to garner required support. This is in keeping with recent research by Plouffe et al. (2016) who suggest that salespeople need to create a "portfolio of relationships." They find that strategic frontline employees who use effective persuasive measures with their internal colleagues are more likely to perform better. We think that this research can be extended to understand how salespeople can use different persuasive tactics with their operations counterparts. Interestingly, Kaski, Niemi, and Pullins (2018), propose an innovative methodology that involved in-depth qualitative interviews, conversation analysis of sales situations, and follow up interviews to analyse rapport building in salespersoncustomer interactions. We think that this methodology could also be applied to understand how salespeople build rapport with their operations management counterpart.

There is research in the domain of customer centricity that identifies ways by which organizations can align their internal departments to deliver customer value (Gulati 2013). For example, Cuevas (2018) suggest that sales professionals will be required to engage with customers to co-create the service and then involve various functions across the supplier organization to deliver it. Similar outcomes have also been suggested by Sharma, Iyer, and Evanschitzky (2008) and by Storbacka, Polsa, and Sääkjärvi (2011). Cuevas (2018) suggests that sales forces need to become more aligned and in some cases integrated with R\&D, operations 
and supply chain functions, but the process is not clear. When we presented some of the findings from this work to the practitioners we interviewed, except for Firms N, R, and T- all other firms claimed that sales and operations got together only when they faced ad-hoc customer situations, thus raising the issue if interdepartmental cohesion is always necessary. This idea to create adhoc sales-operations teams was mentioned by (a) Firm P when faced with very specific, "oneoff” requests by customers, (b) Firm S when they had specific customer complaints, and Firm N when they worked on innovation projects involving voice of customer exercises and market potential exercises for new product planning purposes. Academic research on the nature of adhoc sales-operations teams is limited, but Malshe et al. (2017) focus on how marketers need to work on both strategic and operational alignment with their sales counterparts to achieve their goals. It will be interesting to determine if the findings from this research can be duplicated to a sales and operational team- whose key performance indicators need not be aligned. Another area of potential research could be to measure the performance of these ad-hoc teams and the antecedents of their success. This is in keeping with the work by Johnson et. al (2018), who focus on organizations with malleable sales and marketing teams, which they term as Sales and Marketing Selling Centers (SMSC's). Failure to resolve intra-organizational issues could result in failed sales opportunities (Friend et. al 2014). Future research could extend this research to apply to sales and operations teams to understand the antecedents and consequences of failed sales and operations management collaboration.

Sales/marketing Strategy: There is limited research on sales/marketing strategy in the domain of sales and operations management collaboration except for a few examples (Engelseth and Felzenstein 2012; Laanti, Gabrielsson, and Gabrielsson 2007; and Zarpelon Neto, Pereira, and 
Borchardt 2015). Academic researchers have suggested two interesting questions - should researchers examine sales automation before looking at integration of functions; and, are some sales strategies an impediment to better sales and operations alignment?

Our qualitative research found that a lack of coordination between sales and operations management has a negative impact on firm performance. All the companies we interviewed suggested that for the most part, sales and operations aligned themselves only when they were faced with specific situations that necessitated them to work together. This lead to unnecessary friction between the teams, resulting in increased costs and dissatisfied customers. In our second round of qualitative interviews, we specifically focused on this issue. All the executives we interviewed felt that while the operations management strategy was clearly defined in their organizations, the sales strategy was either not always well defined or was not adhered too. Clearly, more research is needed in this area.

Technology/Sales Force Automation. Barker et al. (2009); Feng, D’Amours, and Beauregard (2013); Sharma and Sheth (2010) and, Zackariasson and Wilson (2004) have addressed the area of technology/sales force automation in the domain of sales and operations management collaboration, but much work remains to be done. The topic of how technology could impact sales operation alignment has generated some interest by academics as they start examining the impact of how advances in technology could facilitate better communication between sales and operations and how new technologies like Artificial Intelligence and Machine Learning could help sales organization better manage their relationship with operations (Syam and Sharma 2018). While academic literature on these topics still remains limited, there seems to be an emerging stream of literature that address some of the issues above. 
In our qualitative studies, we found that our first set of interviews did not discuss technology/sales force automation although investments in technology to enhance collaboration between sales and operations management was highlighted. Interestingly, when this topic was presented to the second set of qualitative studies we conducted, two of the companies in the new sample, Firm L and Firm O indicated that their firms were combining the reports/data from their sales reports (through sales force automation systems) and from their enterprise resource planning (ERP) systems to help generate actionable insights to help better forecast demand for their offerings. This analysis was the responsibility of a separate business analytics unit that helped both sales and operations department better manage their forecasting. Setting up of a separate department to help sales and operations is not an option that other firms were considering, as they felt that this would give rise to unnecessary complication and may lead to either lost opportunities with customers or dissatisfied customers (Firms K, N, S, and T). This is in keeping with work by Virtanen et al. (2015) who suggest that cross business collaborations does not always lead to better sales performance, owing to the possibility of an overload of information from multiple internal sources that cannot be processed by customers.

Interestingly, Balboni and Terho (2016) suggest that most research in business-tobusiness marketing has ignored taking into account salesperson analysis of customer potential and instead has only focused on internal-driven, historical-data that does not always apply in many business-to-business settings. Building on this, we think that sales force automation technologies can help capture salespeople's analysis of their customers; and, this combined with the historical-data (usually captured in internal ERP systems) can lead to better co-operation between sales and operations management. 
Sales Evaluation and Performance. There is limited academic research on sales evaluation and performance in the domain of sales and operations management collaboration. Research by Chen, Lai, and Xiao (2015), Feng, D’Amours, and Beauregard (2008), Lee and Grewal (2004), and Storbacka (2011) are the few exceptions and we think that future research should focus on this area. There is research that suggests that the role of the salesperson should be similar to a general manager with supply chain responsibilities (Sheth and Sharma 2008). Our survey of academic researchers yielded some interesting research questions, including - do contradicting objectives (e.g., sales focusing on high service levels and operations on inventory reduction) increase the tension between different departments; what performance metrics should be used to compensate inside and outside salespeople equitably; and should salespeople be subject to a 360degree evaluation that includes peers from other departments?

Our qualitative research suggested that most firms were changing the evaluation of salespeople from revenue/profits to include operations management measures. Firm X for example was looking into linking an operations department KPI of QOTIF (quality on time in full) to the sales function, owing to the reliance of the operations department on the forecasting accuracy of salespeople. However, the sales organization was not very happy with this evolution. A similar approach was being taken at firm $\mathrm{N}$, a financial services company, where they were taking an innovative approach to ensure the success of new product development and commercialization. In this organization, both the sales and operations department were held jointly responsible to ensure successful new product development and commercial launch.

Another area of possible research involve the different expectations of salespeople regarding their roles in customer delivery. For example, Davies, Ryals, and Holt (2010) suggest that as the role of salespeople evolve more to become relationship managers, salespeople should 
be expected to forge better internal relationships to ensure operational delivery and keeping an efficient supply chain (Harvey et al. 2002; Homburg, Workman, and Jensen 2000, 2002). This is in keeping with the research by Nijssen et al. (2017) who suggest that salespeople who are ambidextrous should focus on cross-functional co-operation if they need to be successful. The next stage of research would be examining sales evaluations and performance.

Forecasting. Our qualitative reviews indicated the need for better forecasting and how companies were trying to address this area. Academic research has also addressed the issues of better forecasting in the domain of sales and operations management collaboration (Cooper and Budd 2007; Doering and Suresh 2016; Feng, D’Amours, and Beauregard 2013; Ivert et al. 2015; Oliva and Watson 2011; Zarpelon Neto, Pereira, and Borchardt 2015). One of the issues that researchers wrestle with is the inaccuracy of salespeople's predictions (Lambert, Marmorstein and Sharma 1990). Academic researchers from our online survey suggested the following areas for future research: how digital data can inform forecasting - seasonality/fluctuation of demand; what are the antecedents and consequences of enhanced forecasting accuracy; and how can one forecast sales using buyers' browsing patterns.

A review of the literature in Operations Research identifies an increasing focus on understanding how advances in technology has enabled firms to capture data about customers that are stored in CRM databases or in Operations databases (Fildes et al. 2008) to help drive forecasting accuracy. Syam and Sharma (2018) highlight key ways in which developments in AI and Machine Learning can help organizations better manage their demand estimation and forecasting. However, extant research outlines a silo-oriented approach used by researchers in the sales domain and the operations domain separately. Fildes et al. (2008) point out that while 
operations researchers have focused on models to manage inventories and the impact of sharing forecast implications down the supply chain, researchers in marketing/sales have used data to aid in forecasting of sales (Syam and Sharma 2018). Future research should focus on combining the sources of data from CRM and ERP systems to help both sales and operations related outcomes. Our qualitative studies did not shed light on this area although most executives suggested that firms need forecasts that are more accurate. This area, therefore, remains an area of further research.

\section{CONCLUSION}

There is a rapid growth in modern sales techniques and strategies such as consultative selling, solution selling, and challenger sales have emerged. The common element in all of these strategies is the role that operations management plays in fulfilling the needs of customers in terms of integrating products and services. Since solution selling and challenger sales have not been universally successful, one possible reason for the lack of success may be the lack of collaboration between sales and operations management. As stated earlier, operations management is typically focused on lean operations and efficiency, and providing customized solutions for customers has not been a priority. The negative effect of the lack of collaboration between sales and operations management was a key finding from extant research as well as the feedback from senior executives in firms.

In order to determine how sales teams and operations management teams should work together to ensure delivery of a firm's offerings, we conducted a deeper examination of this area. We undertook three research projects. First, we undertook qualitative research in two stages by conducting in-depth interviews with senior executives in ten firms on sales and operations 
management collaboration. The primary finding was that close cooperation between sales and operations management is critical for the success of firms. Lack of collaboration leads to revenue loss and harms customer relationships. The interviews also suggested that other functional team involvement, collaborative environment - internally and externally, goal alignment, organizational culture, and, top management involvement positively affected sales and operational management collaboration. We also found that managers supported the five subareas where research is needed - intra-organizational issues; sales/marketing strategy; technology/sales force automation; sales evaluation and performance; and, forecasting .

The second research project was an in-depth review of the research and literature on the interface of sales and operations management. Surprisingly, we found that only twelve articles that addressed both sales and operations management functions. We identified common themes in the research. These were: criticality of sales and operations management collaboration in the success of a firm; sales and operations management alignment can reduce negative effects; sales and operations management alignment can enhance positive effects; internal business relationships are critical in enhancing interactions between sales and operations management; and, what processes can improve sales and operations management collaboration.

Third, we conducted a survey of academic researchers in the area to identify areas and themes of future research in this area. Using the Plouffe, Williams, and Wachner (2008) categorization, respondents suggested that the study of technology/sales force automation, forecasting, sales evaluation and performance, intra-organizational issues, and sales/marketing strategy are the most important areas of study in the domain of sales and operations management. The respondents also suggested some research questions. While the response rate was low, by analyzing and finding few differences between early and late respondents, we feel that the right 
areas were identified. We then presented these gaps to a set of executives to gain their insights into the relevance of these gaps to practice.

Finally, we combined findings and identified our results as well as the direction for future research. There are also interesting new approaches to research and we would suggest examining longitudinal modeling (Bolander, Dugan and Jones 2017). For instance, one of the examples proposed by Bolander, Dugan and Jones (2017), can be modified to ask "What specific salesperson behaviors increase sales-operation management cooperation?” We hope that this paper will serve as an impetus for further research in this critical area. 
TABLES

Table 1: Sample Characteristics

\begin{tabular}{|c|c|c|c|c|}
\hline Firm & Function & Responsibility & Industry & $\begin{array}{l}\text { Annual } \\
\text { Revenue } \\
\text { (USD) }\end{array}$ \\
\hline \multicolumn{5}{|c|}{ Stage 1} \\
\hline A & Director of Sales & Europe & Food and Beverage & 45.52 Billion \\
\hline B & $\begin{array}{l}\text { Supply Chain } \\
\text { Director }\end{array}$ & $\begin{array}{c}\text { Europe, Middle East, } \\
\text { and Africa (EMEA) }\end{array}$ & Commodity Metals & 2.67 Billion \\
\hline $\mathrm{C}$ & $\begin{array}{c}\text { VP Marketing and } \\
\text { Sales } \\
\text { and } \\
\text { VP Operations } \\
\end{array}$ & Global & Industrial Machinery & 11.4 Billion \\
\hline $\mathrm{D}$ & $\begin{array}{l}\text { Supply Chain } \\
\text { Manager }\end{array}$ & EMEA & Industrial Chemicals & 57 Billion \\
\hline $\mathrm{E}$ & VP Sales & Global & Electronic Equipment & 1.2 Billion \\
\hline $\mathrm{F}$ & $\begin{array}{l}\text { Project Manager- } \\
\text { Customer } \\
\text { Excellence }\end{array}$ & Global & Industrial Materials & 4.9 Billion \\
\hline G & $\begin{array}{c}\text { Global Supply Chain } \\
\text { Director } \\
\end{array}$ & Global & $\begin{array}{l}\text { Performance } \\
\text { Materials } \\
\end{array}$ & 9.65 Billion \\
\hline $\mathrm{H}$ & $\begin{array}{l}\text { Chief Financial } \\
\text { Officer } \\
\end{array}$ & Regional & Waste Management & 16 Billion \\
\hline I & $\begin{array}{l}\text { Business Unit } \\
\text { Director } \\
\end{array}$ & Global & Materials Technology & 15 Billion \\
\hline $\mathrm{J}$ & $\begin{array}{c}\text { Service Delivery } \\
\text { Head } \\
\end{array}$ & Regional & Financial Services & 14 Billion \\
\hline \multicolumn{5}{|c|}{ Stage 2} \\
\hline K & $\begin{array}{c}\text { VP Operations } \\
\text { and } \\
\text { VP Sales } \\
\end{array}$ & Global & Mining & 4.5 Billion \\
\hline $\mathrm{L}$ & $\begin{array}{l}\text { VP Business } \\
\text { Development }\end{array}$ & North America & $\begin{array}{c}\text { Industrial Machinery } \\
\text { Rental } \\
\end{array}$ & 250 Million \\
\hline M & $\begin{array}{c}\text { Manager, Sales } \\
\text { Support }\end{array}$ & Regional-Europe & Transportation & 100 Million \\
\hline $\mathrm{N}$ & $\begin{array}{l}\text { Senior Account } \\
\text { Director }\end{array}$ & EMEA & Financial Services & 850 Million \\
\hline $\mathrm{O}$ & $\begin{array}{c}\text { SVP and Business } \\
\text { Unit Head }\end{array}$ & Global & Food Technology & 400 Million \\
\hline $\mathrm{P}$ & VP Sales Operations & EMEA & Medical Devices & 1.1 Billion \\
\hline Q & $\begin{array}{l}\text { Global Sales } \\
\text { Director }\end{array}$ & Global & $\begin{array}{c}\text { Industrial } \\
\text { Construction } \\
\end{array}$ & 400 Million \\
\hline $\mathrm{R}$ & Operations Manager & Regional & Automotive Services & 60 Million \\
\hline$S$ & Sales Director & Europe & Logistics Services & Not provided \\
\hline $\mathrm{T}$ & CEO & North America & Financial Services & 7 Million \\
\hline
\end{tabular}


Table 2: Sampled Articles with a Discussion on the Integration of the Sales and Operations Function

\begin{tabular}{|c|c|c|c|c|}
\hline Citation & $\begin{array}{l}\text { Empirical or } \\
\text { Conceptual? }\end{array}$ & $\begin{array}{l}\text { Who is Data } \\
\text { Collected } \\
\text { from? }\end{array}$ & $\begin{array}{l}\text { Whose needs } \\
\text { are } \\
\text { addressed? }\end{array}$ & Key Finding(s) \\
\hline $\begin{array}{l}\text { Chen, Lai, and } \\
\text { Xiao (2015) }\end{array}$ & Conceptual & $\begin{array}{l}\text { No Primary } \\
\text { Data }\end{array}$ & $\begin{array}{l}\text { Sales and } \\
\text { Operations } \\
\text { Management }\end{array}$ & $\begin{array}{l}\text { Salespeople are ideally positioned to collect the necessary market } \\
\text { information for enhancing the company's production planning at a low } \\
\text { cost. }\end{array}$ \\
\hline $\begin{array}{l}\text { Cooper and Budd } \\
\text { (2007) }\end{array}$ & Conceptual & $\begin{array}{l}\text { No Primary } \\
\text { Data }\end{array}$ & $\begin{array}{l}\text { Sales and } \\
\text { Operations } \\
\text { Management }\end{array}$ & $\begin{array}{l}\text { Presentation of a theoretical model that synchronizes the sales funnel and } \\
\text { project operations into the whole marketing project cycle. }\end{array}$ \\
\hline $\begin{array}{l}\text { Feng, D'Amours, } \\
\text { and Beauregard } \\
(2008)\end{array}$ & $\begin{array}{l}\text { Empirical: } \\
\text { One case } \\
\text { study }\end{array}$ & $\begin{array}{l}\text { Sales and } \\
\text { Operations } \\
\text { Management }\end{array}$ & $\begin{array}{l}\text { Sales and } \\
\text { Operations } \\
\text { Management }\end{array}$ & $\begin{array}{l}\text { A supply-chain-based sales and operations management provides superior } \\
\text { performance than sales-production-based sales and operations management } \\
\text { and decoupled planning in all cases. }\end{array}$ \\
\hline $\begin{array}{l}\text { Feng, Martel, } \\
\text { D’Amours, and } \\
\text { Beauregard (2013) }\end{array}$ & $\begin{array}{l}\text { Empirical: } \\
\text { One case } \\
\text { study }\end{array}$ & $\begin{array}{l}\text { Sales and } \\
\text { Operations } \\
\text { Management }\end{array}$ & Sales & $\begin{array}{l}\text { The authors propose a make-to-order model that should lead to better } \\
\text { manufacturer decisions. They suggest a decrease in the number of customer } \\
\text { contract offers when the economy is unstable in order to end up with less } \\
\text { non-profitable contract obligations. }\end{array}$ \\
\hline $\begin{array}{l}\text { Ivert, Dukovska } \\
\text { Popovska, } \\
\text { Fredriksson, } \\
\text { Dreyer, and Kaipia } \\
\text { (2015) }\end{array}$ & $\begin{array}{l}\text { Empirical: } \\
\text { Multiple case } \\
\text { studies }\end{array}$ & $\begin{array}{l}\text { Sales and } \\
\text { Operations } \\
\text { Management }\end{array}$ & $\begin{array}{l}\text { Sales and } \\
\text { Operations } \\
\text { Management }\end{array}$ & $\begin{array}{l}\text { Identify a new set of contingencies connected to supply needs that should } \\
\text { be incorporated into the sales and operations management setup and } \\
\text { process, such as uncertainty connected to demand and material supply, } \\
\text { frequent product launches and production network complexity. }\end{array}$ \\
\hline
\end{tabular}




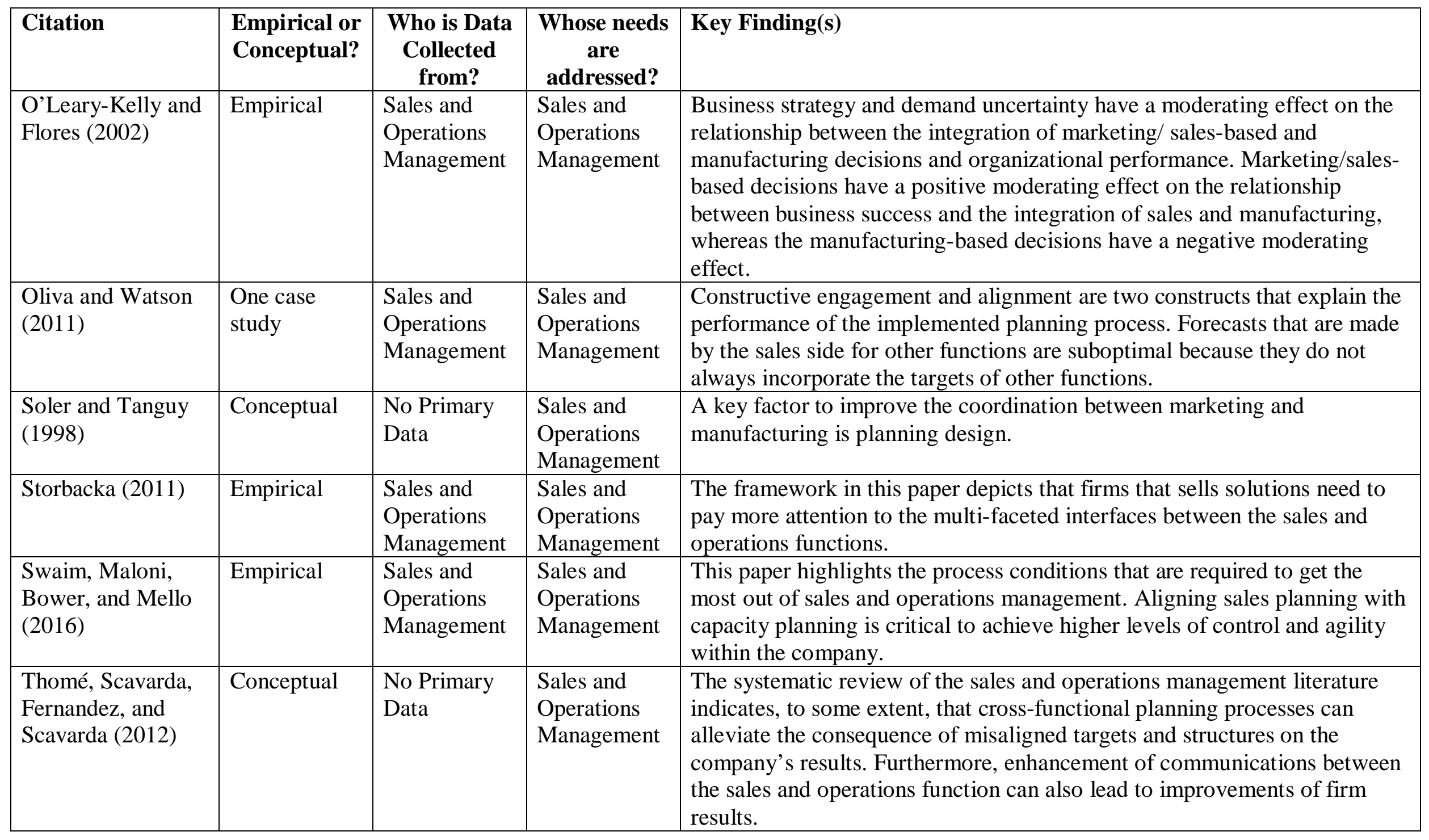




\begin{tabular}{|c|c|c|c|c|}
\hline Citation & $\begin{array}{l}\text { Empirical or } \\
\text { Conceptual? }\end{array}$ & $\begin{array}{l}\text { Who is Data } \\
\text { Collected } \\
\text { from? }\end{array}$ & $\begin{array}{c}\text { Whose needs } \\
\text { are } \\
\text { addressed? }\end{array}$ & Key Finding(s) \\
\hline $\begin{array}{l}\text { Toon, Morgan, } \\
\text { Lindgreen, } \\
\text { Vanhamme, and } \\
\text { Hingley (2016) }\end{array}$ & $\begin{array}{l}\text { One case } \\
\text { study }\end{array}$ & $\begin{array}{l}\text { Sales and } \\
\text { Operations } \\
\text { Management }\end{array}$ & $\begin{array}{l}\text { Sales and } \\
\text { Operations } \\
\text { Management }\end{array}$ & $\begin{array}{l}\text { The framework in this paper focuses on internal organizational integration. } \\
\text { The authors highlight the relation between internal integration and } \\
\text { operational efficiency, and they suggest that focusing on cost is vital in low } \\
\text { variation settings, whereas knowledge transfers between functions is more } \\
\text { important in innovative scenarios. }\end{array}$ \\
\hline $\begin{array}{l}\text { Tuomikangas and } \\
\text { Kaipia (2014) }\end{array}$ & Conceptual & $\begin{array}{l}\text { No Primary } \\
\text { Data }\end{array}$ & $\begin{array}{l}\text { Sales and } \\
\text { Operations } \\
\text { Management }\end{array}$ & $\begin{array}{l}\text { This literature review shed light on two main avenues for future research in } \\
\text { the sales and operations management area. One is that more empirical } \\
\text { studies are needed to examine the complexity of sales and operations } \\
\text { management and how this should be implemented. As a second avenue for } \\
\text { future research, this paper emphasizes the need to study how sales and } \\
\text { operations management can be used to achieve company objectives. }\end{array}$ \\
\hline $\begin{array}{l}\text { Turkulainen, } \\
\text { Kujala, Artto, and } \\
\text { Levitt (2013) }\end{array}$ & $\begin{array}{l}\text { One case } \\
\text { study }\end{array}$ & $\begin{array}{l}\text { Sales and } \\
\text { Operations } \\
\text { Management }\end{array}$ & $\begin{array}{l}\text { Sales and } \\
\text { Operations } \\
\text { Management }\end{array}$ & $\begin{array}{l}\text { This article points out that organizational design needs more detail in order } \\
\text { to fully grasp and implement the managerial problems. The associated } \\
\text { needs and mechanisms are strongly influenced by contextual factors, and } \\
\text { thus vary, not only across company level, but also among individual } \\
\text { projects. }\end{array}$ \\
\hline $\begin{array}{l}\text { Mentzer, Stank, } \\
\text { and Esper (2008) }\end{array}$ & Conceptual & $\begin{array}{l}\text { No Primary } \\
\text { Data }\end{array}$ & $\begin{array}{l}\text { Sales and } \\
\text { Operations } \\
\text { Management } \\
\end{array}$ & $\begin{array}{l}\text { This article presents a classification framework from the perspective of } \\
\text { both sides -marketing (sales) and operations- on decision scopes and } \\
\text { functional areas. }\end{array}$ \\
\hline $\begin{array}{l}\text { Kaipia, } \\
\text { Holmström, } \\
\text { Småros, and Rajala } \\
\text { (2017) }\end{array}$ & Case studies & $\begin{array}{l}\text { Sales and } \\
\text { Operations } \\
\text { Management }\end{array}$ & $\begin{array}{l}\text { Sales and } \\
\text { Operations } \\
\text { Management }\end{array}$ & $\begin{array}{l}\text { This paper demonstrates, based on a set of contextual factors, whether the } \\
\text { manufacturer should consider collaborative sales and operations } \\
\text { managment processes. }\end{array}$ \\
\hline
\end{tabular}




\begin{tabular}{|l|l|l|l|l|}
\hline Citation & $\begin{array}{l}\text { Empirical or } \\
\text { Conceptual? }\end{array}$ & $\begin{array}{l}\text { Who is Data } \\
\text { Collected } \\
\text { from? }\end{array}$ & $\begin{array}{l}\text { Whose needs } \\
\text { are } \\
\text { addressed? }\end{array}$ & Key Finding(s) \\
\hline $\begin{array}{l}\text { Esper, Ellinger, } \\
\text { Stank, Flint, and } \\
\text { Moon (2010) }\end{array}$ & Conceptual & $\begin{array}{l}\text { No Primary } \\
\text { Data }\end{array}$ & $\begin{array}{l}\text { Sales and } \\
\text { Operations } \\
\text { Management }\end{array}$ & $\begin{array}{l}\text { This paper states that value creation through intra-organizational } \\
\text { knowledge management between supply chain and marketing/sales serves } \\
\text { as a basis for creating customer value. }\end{array}$ \\
\hline $\begin{array}{l}\text { Patel, Azadegan, } \\
\text { and Ellram (2013) }\end{array}$ & Empirical & Operations & $\begin{array}{l}\text { Sales and } \\
\text { Operations } \\
\text { Management }\end{array}$ & $\begin{array}{l}\text { This article points out that strategic supply chain operation is linked to } \\
\text { customer-focused and operational performance. However, the results } \\
\text { indicate that structural supply chain operation is only associated with } \\
\text { operational performance. }\end{array}$ \\
\hline
\end{tabular}


Table 3

Matching Qualitative Findings with Literature Review and Academic Survey

\begin{tabular}{|c|c|c|}
\hline Case Study Themes & Literature review & Research Questions from Academic Survey \\
\hline Other functional team involvement & & $\begin{array}{l}\text { Do contradicting objectives (e.g., sales focusing on high service } \\
\text { levels and operations on inventory reduction) increase the tension } \\
\text { between different departments? }\end{array}$ \\
\hline $\begin{array}{l}\text { Involvement of other functional domains like } \\
\text { finance, product management etc. }\end{array}$ & $\begin{array}{l}\text { Feng, D'Amours, and } \\
\text { Beauregard (2008) }\end{array}$ & $\begin{array}{l}\text { What performance metrics should be used to compensate inside } \\
\text { (operations management) and outside salespeople equitably? }\end{array}$ \\
\hline $\begin{array}{l}\text { Too much data available, need for business } \\
\text { analytics }\end{array}$ & Storbacka (2011) & $\begin{array}{l}\text { How can digital data inform forecasting - seasonality / fluctuation of } \\
\text { demand? }\end{array}$ \\
\hline Difficulty in common KPI setting & $\begin{array}{l}\text { Toon, Morgan, Lindgreen, } \\
\text { Vanhamme, and Hingley } \\
(2016)\end{array}$ & How can one forecast sales using buyers' browsing patterns? \\
\hline \multicolumn{3}{|l|}{ Creation of an interface department } \\
\hline \multicolumn{3}{|l|}{ Collaboration: Internal/external } \\
\hline Mandatory cross-functional meetings & $\begin{array}{l}\text { Wagner, Ullrich, and } \\
\text { Transchel (2014) }\end{array}$ & \\
\hline Joint meeting- sales/operation/customers & $\begin{array}{l}\text { Engelseth and Felzensztein } \\
\text { (2012) }\end{array}$ & \\
\hline Increased client engagement to unite sales/op & $\begin{array}{l}\text { Ivert, Dukovska Popovska, } \\
\text { Fredriksson, Dreyer, and } \\
\text { Kaipia (2015) }\end{array}$ & \\
\hline Client Incentives to unite sales and operations & $\begin{array}{l}\text { Oliva and Watson (2011); } \\
\text { Storbacka (2011) }\end{array}$ & $\begin{array}{l}\text { What are the conflicts between personal selling and sales } \\
\text { management and operations management? } \\
\text { Tools for managing in the era of new customer decision journey? }\end{array}$ \\
\hline Goal Alignment & & $\begin{array}{l}\text { How can the goals of personal selling and sales management and } \\
\text { operations management be aligned? }\end{array}$ \\
\hline $\begin{array}{l}\text { Sales and operations outcomes aligned with } \\
\text { overall business }\end{array}$ & $\begin{array}{l}\text { Swaim, Maloni, Bower, and } \\
\text { Mello (2016) }\end{array}$ & $\begin{array}{l}\text { What incentives drive personal selling and sales management and } \\
\text { operations management integration? }\end{array}$ \\
\hline
\end{tabular}




\begin{tabular}{|c|c|c|}
\hline Top management KPI alignment & $\begin{array}{l}\text { O’Leary-Kelly, and Flores } \\
\text { (2002) }\end{array}$ & \\
\hline \multicolumn{3}{|l|}{$\begin{array}{l}\text { Salespeople getting overall customer } \\
\text { satisfaction targets }\end{array}$} \\
\hline $\begin{array}{l}\text { Sales/operation responsible for accurate } \\
\text { forecasting }\end{array}$ & $\begin{array}{l}\text { Feng, Martel, D’Amours, } \\
\text { and Beauregard (2013) }\end{array}$ & $\begin{array}{l}\text { How can technology (AI, Machine learning) help operations } \\
\text { management forecast demand from examining sales software (e.g., } \\
\text { salesforce.com)? } \\
\text { How does sales automation effect operations management in better } \\
\text { forecasting? }\end{array}$ \\
\hline \multicolumn{3}{|l|}{ Organizational Culture } \\
\hline \multicolumn{3}{|l|}{ Job rotations } \\
\hline \multicolumn{3}{|l|}{$\begin{array}{l}\text { Special organizational programs to promote } \\
\text { collaboration }\end{array}$} \\
\hline \multicolumn{3}{|l|}{ Joint training programs } \\
\hline \multicolumn{3}{|l|}{ Top Management Involvement } \\
\hline Organizational structure change & $\begin{array}{l}\text { Turkulainen, Kujala, Artto, } \\
\text { and Levitt (2013) }\end{array}$ & $\begin{array}{l}\text { How does ICT (internet communication technologies) affect sales } \\
\text { force structure (i.e., the composition and split between inside } \\
\text { (operations management) and outside salespeople)? } \\
\text { Should researchers examine sales automation before looking at } \\
\text { integration of functions? }\end{array}$ \\
\hline
\end{tabular}


Table 4: Summary of Findings Using Questionnaire

\begin{tabular}{|c|c|c|c|}
\hline $\begin{array}{l}\text { Topic Plouffe, } \\
\text { Williams, and } \\
\text { Wachner } \\
\text { (2008) }\end{array}$ & $\begin{array}{l}\text { Qualitative } \\
\text { Research }\end{array}$ & Literature Survey & Sample Research Questions (from Survey of Academic Researchers) \\
\hline \multicolumn{4}{|l|}{ Firm-Level } \\
\hline $\begin{array}{l}\text { Intra- } \\
\text { organizational } \\
\text { issues }\end{array}$ & $\begin{array}{l}\text { Other functional } \\
\text { team } \\
\text { involvement; } \\
\text { collaborative } \\
\text { environment: } \\
\text { internally and } \\
\text { externally; goal } \\
\text { alignment; } \\
\text { organizational } \\
\text { culture; and, top } \\
\text { management } \\
\text { involvement. }\end{array}$ & $\begin{array}{l}\text { Engelseth and Felzensztein (2012); } \\
\text { Chen, Lai, and Xiao (2015); Feng, } \\
\text { D’Amours, and Beauregard (2008); } \\
\text { Ferrel, Ingram, LaForge (2000); } \\
\text { Grimson and Pycke (2007); O’Leary- } \\
\text { Kelly and Flores (2002); Oliva and } \\
\text { Watson (2011); Randall, Netessine, and } \\
\text { Rudi (2006); Soler and Tanguy (1998); } \\
\text { Storbacka (2011); Swaim et al. (2016); } \\
\text { Toon et al. (2016); Wagner, Ullrich, and } \\
\text { Transchel (2014); Wilson, Boström, and } \\
\text { Lundin (1999); Zackariasson and } \\
\text { Wilson (2004); Zarpelon Neto, Pereira, } \\
\text { and Borchardt (2015) }\end{array}$ & $\begin{array}{l}\text { - Top performing salespeople have high reputational effective and are able } \\
\text { to garner required support. What sets them apart? } \\
\text { - What incentives drive personal selling and sales management and } \\
\text { operations management integration? } \\
\text { - What are the conflicts between personal selling and sales management } \\
\text { and operations management? } \\
\text { - How can the goals of personal selling and sales management and } \\
\text { operations management be aligned? }\end{array}$ \\
\hline $\begin{array}{l}\text { Sales/ } \\
\text { marketing } \\
\text { strategy }\end{array}$ & $\begin{array}{l}\text { Negative impact } \\
\text { of lack of } \\
\text { coordination }\end{array}$ & $\begin{array}{l}\text { Engelseth and Felzenstein (2012); } \\
\text { Laanti, Gabrielsson, and Gabrielsson } \\
\text { (2007); Zarpelon Neto, Pereira, and } \\
\text { Borchardt (2015) }\end{array}$ & $\begin{array}{l}\text { - Should researchers examine sales automation before looking at } \\
\text { integration of functions? } \\
\text { - Understanding the relationship between sales strategy and enhanced } \\
\text { operations management. } \\
\text { - Is sales strategy an impediment to better forecasting? }\end{array}$ \\
\hline
\end{tabular}




\begin{tabular}{|c|c|c|c|}
\hline \multicolumn{4}{|c|}{ Sales Management-Level } \\
\hline $\begin{array}{l}\text { Technology/ } \\
\text { sales force } \\
\text { automation }\end{array}$ & $\begin{array}{l}\text { Combining data } \\
\text { from sales with } \\
\text { historical data to } \\
\text { create business } \\
\text { insights. }\end{array}$ & $\begin{array}{l}\text { Barker et al. (2009); Feng et al. (2013); } \\
\text { Zackariasson and Wilson (2004) }\end{array}$ & $\begin{array}{l}\text { - How does ICT (internet communication technologies) affect sales force } \\
\text { structure (i.e., the composition and split between inside (operations } \\
\text { management) and outside salespeople)? } \\
\text { - What type of technology will enhance personal selling and sales } \\
\text { management and operations management coordination? } \\
\text { - How can technology (AI, Machine learning) help operations management } \\
\text { forecast demand from examining sales software (e.g., salesforce.com)? } \\
\text { - How does sales automation effects operations management in better } \\
\text { forecasting? }\end{array}$ \\
\hline $\begin{array}{l}\text { Sales } \\
\text { evaluation and } \\
\text { performance }\end{array}$ & $\begin{array}{l}\text { Changing the } \\
\text { evaluation of } \\
\text { salespeople to } \\
\text { include } \\
\text { operations } \\
\text { measures. }\end{array}$ & $\begin{array}{l}\text { Chen, Lai, and Xiao (2015); Feng, } \\
\text { D’Amours, and Beauregard (2008); Lee } \\
\text { and Grewal (2004); Storbacka (2011) }\end{array}$ & $\begin{array}{l}\text { - Do contradicting objectives (e.g., sales focusing on high service levels } \\
\text { and operations on inventory reduction) increase the tension between } \\
\text { different departments? } \\
\text { - What performance metrics should be used to compensate inside } \\
\text { (operations management) and outside salespeople equitably? } \\
\text { - Should salespeople evaluation be a } 360 \text { evaluation? }\end{array}$ \\
\hline \multicolumn{4}{|c|}{ Salesperson-Level } \\
\hline Forecasting & $\begin{array}{l}\text { Issue of } \\
\text { enhanced } \\
\text { accuracy of } \\
\text { forecasting } \\
\text { discussed. }\end{array}$ & $\begin{array}{l}\text { Cooper and Budd (2007); Doering and } \\
\text { Suresh (2016); Feng et al. (2013); Ivert } \\
\text { et al. (2015); Oliva and Watson (2011); } \\
\text { Zarpelon Neto, Pereira, Borchardt } \\
\text { (2015) }\end{array}$ & $\begin{array}{l}\text { - How can digital data inform forecasting - seasonality / fluctuation of } \\
\text { demand? } \\
\text { - Forecasting has to take the industry sector into account. it can be done } \\
\text { and needs to be done completely different in different sectors. } \\
\text { - How can a firm enhance forecasting accuracy? } \\
\text { - What are the antecedents and consequences of enhanced forecasting } \\
\text { accuracy? } \\
\text { - How can one forecast sales using buyers' browsing patterns? }\end{array}$ \\
\hline
\end{tabular}


Figure 1

Areas of Future Research

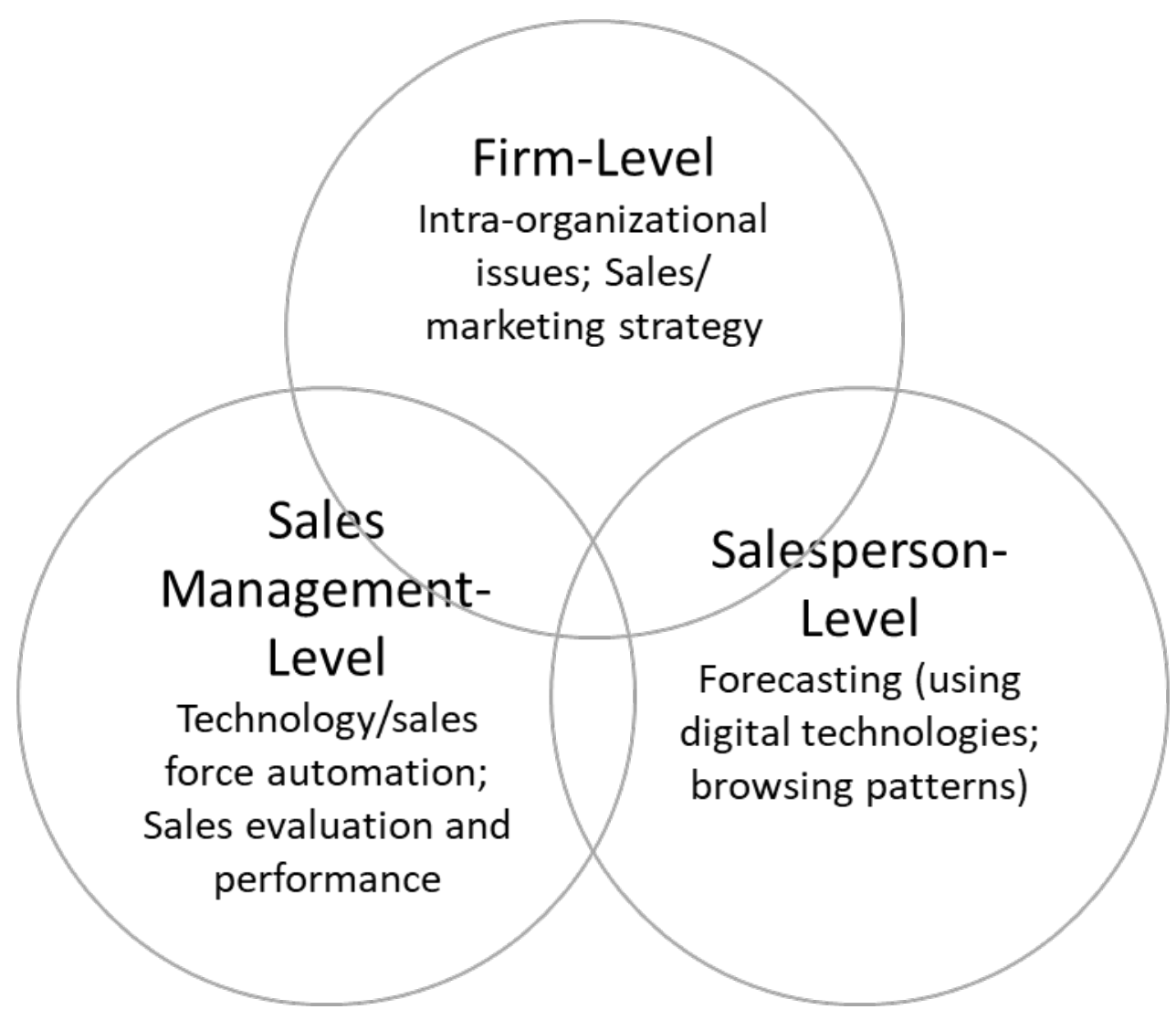




\section{REFERENCES}

Balboni, Bernardo., and Terho, Harry. (2016). Outward-looking and future-oriented customer value potential management: The sales force value appropriation role. Industrial Marketing Management, 53 (2016): 181-193.

Barker, Robert M, Gohmann, Stephan F, Guan, Jian, and Faulds, David J. (2009). Why is my sales force automation system failing? Business Horizons, 52(3), 233-241.

Beer, Michael, Spector, B., Lawrence, P. R., \& Mills, D. Q. (1985). Managing human assets: I. A general manager's perspective. Personnel Administrator.

Bernard, H.R. (2012). Social Methods Research: Qualitative and Quantitative Approaches. Sage Publishing.

Bolander, Willy, Riley Dugan \& Eli Jones (2017). Time, change, and longitudinally emergent conditions: understanding and applying longitudinal growth modeling in sales research, Journal of Personal Selling \& Sales Management, 37:2, 153-159.

Brewer, M. B., \& Kramer, R. M. (1986). Choice behavior in social dilemmas: Effects of social identity, group size, and decision framing. Journal of Personality and Social Psychology, 50(3), 543.

Chen, Fangruo, Lai, Guoming, and Xiao, Wenqiang. (2015). Provision of Incentives for Information Acquisition: Forecast-Based Contracts vs. Menus of Linear Contracts. Management Science, 62(7), 1899-1914.

Christopher, M. (1998). Logistics and supply chain management: strategies for reducing cost. Improving Services. 1992, London: Pitman, 231.

Cilliers, Frans, and Greyvenstein, Henk. (2012). The impact of silo mentality on team identity: an organisational case study. SA Journal of Industrial Psychology, 38(2), 7584.

Cron, William L., Baldauf, A., Leigh, T. W., and Grossenbacher, S. (2014). The strategic role of the sales force: perceptions of senior sales executives. Journal of the Academy of Marketing Science, 42(5), 471-489.

Cooper, Marjorie J, and Budd, Charlene Spoede. (2007). Tying the pieces together: A normative framework for integrating sales and project operations. Industrial Marketing Management, 36(2), 173-182.

Cuevas, Javier Marcos. (2018). The Transformation of Professional Selling: Implications for Leading the Sales Organization. Industrial Marketing Management, forthcoming.

Dahler-Larsen, P. (1998). What 18 case studies of organizational culture tell us about counter-intentional effects of attempts to establish shared values in organizations? Current topics in management, 3, 151-173.

Davies, Iain A., Ryals, Lynette J., and Holt, Sue. (2010). Relationship Management: A sales role, or a state of mind? An investigation of functions and attitudes across a businessto-business sales force. Industrial Marketing Management, 39 (2010): 1049-1062.

Doering, Torsten, and Suresh, Nallan C. (2016). Forecasting and Performance: Conceptualizing Forecasting Management Competence as a Higher-Order Construct. Journal of Supply Chain Management, 52(4), 77-91.

Diamond, M., and Allcorn, Sheth. (2009). Private selves in public organizations: The psychodynamics of organizational diagnosis and change. Springer.

Eisenhardt, Kathleen M. (1989). Building theories from case study research. Academy of Management review, 14(4), 532-550.

Engelseth, Per, and Felzensztein, Christian. (2012). Intertwining relationship marketing with supply chain management through Alderson's transvection. Journal of Business and Industrial Marketing, 27(8), 673-685. 
Enz, Matias G., and Lambert, Douglas M. (2015). Measuring the Financial Benefits of CrossFunctional Integration Influences Management's Behavior. Journal of Business Logistics, 36(1), 25-48.

Esper, Terry; Ellinger, Alexander; Stank, Theodore; Flint, Daniel; Moon, Mark. (2010). Demand and Supply Integration: a conceptual framework of value creation through knowledge management. Journal of the Academy of Marketing Science. 38(1), 5-18.

Feng, Yan, D’Amours, Sophie, and Beauregard, Robert. (2008). The value of sales and operations planning in oriented strand board industry with make-to-order manufacturing system: Cross functional integration under deterministic demand and spot market recourse. International Journal of Production Economics, 115(1), 189209.

— contract decisions in a make-to-order manufacturing supply chain: A stochastic programming approach. Production and operations management, 22(3), 642-660.

Ferrell, OC, Ingram, Thomas N, and LaForge, Raymond W. (2000). Initiating structure for legal and ethical decisions in a global sales organization. Industrial Marketing Management, 29(6), 555-564.

Fildes, R., Nikolopoulos, K., Crone, S. F., and Synetos, A. A. (2008). Forecasting and operational research: A review. Journal of the Operational Research Society. 59: 1150-1172.

Frankel, Robert; Mollenkopf, Diane A. (2015). Cross-Functional integration revisited. Journal of Business Logistics, 36(1), 18-24.

Friend, Scott B., Curasi, Carolyn F., Boles, James S., and Bellenger, Danny N. (2014). Why are you really losing sales opportunities? A buyers' perspective on the determinants of key account sales failures. Industrial Marketing Management, 43 (2014): 1124-1135.

Glaser, Barney, \& Strauss, Anselm (1967). Grounded theory: The discovery of grounded theory. The Journal of the British Sociological Association, 12, 27-49.

Greenberg, Jerald, and Baron, Robert A. (1995). Behavior in organizations: Understanding and managing the human side of work (Doctoral dissertation, Univerza v Mariboru, Ekonomsko-poslovna fakulteta).

Grimson, J Andrew, and Pyke, David F. (2007). Sales and operations planning: an exploratory study and framework. The International Journal of Logistics Management, 18(3), 322-346.

Grier, Sonya A., and Deshpandé, Rohit (2001). Social dimensions of consumer distinctiveness: The influence of social status on group identity and advertising persuasion. Journal of Marketing Research, 38(2), 216-224.

Gulati, Ranjay. (2013). Reorganize for resilience: Putting customers at the center of your business: Harvard Business Press.

Gupta, Shruti, and Ogden, Denise T. (2009). To buy or not to buy? A social dilemma perspective on green buying. Journal of Consumer Marketing, 26(6), 376.

Harvey, M., Myers, Myers, M.B., and Novicevic, M.M. (2002). The managerial issues with global account management. Thunderbird International Business Review, 44(5): 625647.

Higgins, Julian P., and Green, Sally (2011). Cochrane handbook for systematic reviews of interventions (Vol. 4). John Wiley \& Sons.

Homburg, Christian., Workman, J. P. Jr., and Jensen, Ove. (2000). Fundamental changes in the marketing organization: The movement towards a customer-focused organizational structure. Journal of the Academy of Marketing Science, 28(4): 459478. 
Homburg, Christian., Workman, J. P. Jr., and Jensen, Ove. (2002). A configurational perspective on key account management. Journal of Marketing, 66(2): 38-63.

Homburg, Christian, and Jensen, Ove. (2007). The thought worlds of marketing and sales: which differences make a difference? Journal of Marketing, 71(3), 124-142.

Ivert, Linea Kjellsdotter, Dukovska-Popovska, Iskra, Fredriksson, Anna, Dreyer, Heidi C, and Kaipia, Riikka. (2015). Contingency between S\&OP design and planning environment. International Journal of Physical Distribution and Logistics Management, 45(8), 747-773.

Johansson, Juliet E, Krishnamurthy, Chandru, and Schlissberg, Henry E. (2003). Solving the solutions problem. Mckinsey quarterly (3), 116-125.

Johnson, Jeff S., Matthes, Joseph M., and Friend, Scott B. (2018). Interfacing and customerfacing: Sales and marketing selling centers. Industrial Marketing Management, forthcoming.

Kaipia, Riikka, Holmström, Jan, Småros, Johanna, and Rajala, Risto. (2017). Information sharing for sales and operations planning: Contextualized solutions and mechanisms. Journal of Operations Management, 52, 15-29.

Kaski, Timo., Niemi, Jarkko., and Pullins, Ellen. (2018). Rapport building in authentic B2B Sales Interaction. Industrial Marketing Management, forthcoming.

Kotler, Philip, Rackham, Neil, and Krishnaswamy, Suj. (2006). Ending the war between sales and marketing. Harvard Business Review, 84(7/8), 68.

Kumar, Nirmalya. (2004). Marketing as Strategy: Understanding the CEO's Agenda for driving Growth and Innovation: Harvard Business Review Press.

Lambert, Douglas M., Howard Marmorstein, and Arun Sharma (1990), "Industrial Salespeople as a Source of Market Information,” Industrial Marketing Management, Vol. 19, No. 2, May, 141-48.

Laanti, Riku, Gabrielsson, Mika, and Gabrielsson, Peter. (2007). The globalization strategies of business-to-business born global firms in the wireless technology industry. Industrial Marketing Management, 36(8), 1104-1117.

Lapide, Larry. (2002). New developments in business forecasting. The Journal of Business Forecasting, 21(2), 11.

Lee, Hau L, Padmanabhan, Venkata, and Whang, Seungjin. (1997). Information distortion in a supply chain: The bullwhip effect. Management Science, 43(4), 546-558.

Lee, Ruby P, and Grewal, Rajdeep. (2004). Strategic responses to new technologies and their impact on firm performance. Journal of Marketing, 68(4), 157-171.

Lincoln, Yvonna S., and Guba, Egon G. (1985). Naturalistic inquiry (Vol. 75). Sage.

Malhotra, Manoj K, and Sharma, Subhash. (2002). Spanning the continuum between marketing and operations. Journal of Operations Management, 20(3), 209-219.

Malshe, Avinash., Friend, Scott B., Al-Khatib, Jamal., Al-Haddib, Mohammed I., and Habiballah, Mohammed A. (2017). Strategic and operational alignment of salesmarketing interfaces: Dual paths within a SME configuration. Industrial Marketing Management, 66 (2017): 145-158.

Mentzer, J. T., Stank, T. P., and Esper, T. L. (2008). Supply chain management and its relationship to logistics, marketing, production, and operations management. Journal of Business Logistics, 29(1), 31-46.

Miller, Jeffrey G.; Arnold, Peter. (1998). POM teaching and research in the 21st century. Production and Operations Management, 7(2): 99-105.

Nauta, A., De Dreu, C. K., \& Van Der Vaart, T. (2002). Social value orientation, organizational goal concerns and interdepartmental problem-solving behavior. Journal of Organizational Behavior, 23(2), 199-213. 
Neu, Wayne A, and Brown, Stephen W. (2005). Forming successful business-to-business services in goods-dominant firms. Journal of Service Research, 8(1), 3-17.

Nijssen, Edwin J., Guenzi, Paolo., and Borgh, Michel van der. (2017). Beyond the retentionacquisition trade-off: Capabilities of ambidextrous sales organizations. Industrial Marketing Management, 64 (2017): 1-13.

O’Leary-Kelly, Scott W, and Flores, Benito E. (2002). The integration of manufacturing and marketing/sales decisions: impact on organizational performance. Journal of Operations Management, 20(3), 221-240.

Oliva, Rogelio, and Watson, Noel. (2011). Cross-functional alignment in supply chain planning: A case study of sales and operations planning. Journal of Operations Management, 29(5), 434-448.

Paesbrugghe, Bert, Sharma, Arun, Rangarajan, Deva, and Syam Niladri. (2018). "Personal Selling and the Purchasing Function: Where do We Go From Here?". Journal of Personal Selling and Sales Management. Forthcoming.

Pagell, Mark. (2004). Understanding the factors that enable and inhibit the integration of operations, purchasing and logistics. Journal of Operations Management, 22(5), 459487.

Patel, P. C., Azadegan, A., \& Ellram, L. M. (2013). The Effects of Strategic and Structural Supply Chain Orientation on Operational and Customer-Focused Performance. Decision Sciences, 44(4), 713-753.

Plouffe, Christopher R., Bolander, Willy., Cote, Joseph A., and Hochstein, Bryan. (2016). Does the customer matter most? Exploring strategic frontline employees' influence of customer, the internal team, and external business partners. Journal of Marketing,80 (1): 106-123

Plouffe, Christopher R, Williams, Brian C, and Wachner, Trent. (2008). Navigating difficult waters: Publishing trends and scholarship in sales research. Journal of Personal Selling and Sales Management, 28(1), 79-92.

Randall, Taylor, Netessine, Serguei, and Rudi, Nils. (2006). An empirical examination of the decision to invest in fulfilment capabilities: A study of internet retailers. Management Science, 52(4), 567-580.

Randel, Amy E. (2002). Identity salience: A moderator of the relationship between group gender composition and work group conflict. Journal of Organizational Behavior, 23(6), 749-766.

Rapp, Adam A., Daniel G. Bachrach, Karen Flaherty, Douglas E. Hughes, Arun Sharma, and Clay M. Voorhees (2017), “The Role of the Sales-Service Interface and Ambidexterity in the Evolving Organization: A Multilevel Research Agenda,” Journal of Service Research, 20, 1, 59-75.

Reichheld, Frederick F. (2003). The one number you need to grow. Harvard Business Review, 81(12), 46-55.

Shapiro, Bensen P. (1977). Can marketing and manufacturing co-exist? Harvard Business Review, 55(5), 104.

Sharma, A., Iyer, G. R., \& Evanschitzky, H. (2008). Personal selling of high-technology products: The solution-selling imperative. Journal of Relationship Marketing, 7(3), 287-308.

Sharma, Arun and Jagdish N. Sheth (2010), “A Framework of Technology Mediation in Consumer Selling: Implications for Firms and Sales Management,” Journal of Personal Selling and Sales Management, 30, 2 (Spring), 121-29.

Sharma, Arun, and Gopalkrishnan R. Iyer (2011), "Are pricing policies an impediment to the success of customer solutions?" Industrial Marketing Management, 40, no. 5: 723729. 
Sheth, Jagdish N., and Arun Sharma (2006), "Surpluses and Shortages in B2B markets," Journal of Business and Industrial Marketing, 21, 7, 422-27.

Sheth, Jagdish N. and Arun Sharma (2008), "The Impact of Transitioning from Products to Services in Business and Industrial Markets on the Evolution of the Sales Organization,” Industrial Marketing Management, 37, 260-269.

Soler, LG, and Tanguy, H. (1998). Coordination between production and commercial planning: organisational and modelling issues. International Transactions in Operational Research, 5(3), 171-188.

St. John, Caron H. (1991). Marketing and manufacturing agreement on goals and planned actions. Human Relations, 44(3), 211-229.

Stanley, Jennifer and Philip Wojcik (2005), “Better B2B Selling,” McKinsey Quarterly, 38 (3), 15.

Storbacka, Kaj. (2011). A solution business model: Capabilities and management practices for integrated solutions. Industrial Marketing Management, 40(5), 699-711.

Storbacka, K., Polsa, P., \& Sääksjärvi, M. (2011). Management practices in solution sales—a multilevel and cross-functional framework. Journal of Personal Selling \& Sales Management, 31(1), 35-54.

Swaim, James Anthony, Maloni, Michael, Bower, Patrick, and Mello, John. (2016). Antecedents to effective sales and operations planning. Industrial Management and Data Systems, 116(6), 1279-1294.

Swink, Morgan, and Schoenherr, Tobias (2015). The Effects of Cross-Functional Integration on Profitability, Process Efficiency, and Asset Productivity. Journal of Business Logistics, 36(1), 69-87.

Syam, Niladri and Arun Sharma (2018), "Waiting for a Sales Renaissance in the Fourth Industrial Revolution: Machine Learning and Artificial Intelligence in Sales Research and Practice,” Industrial Marketing Management, forthcoming.

Thomé, Antônio Márcio Tavares, Scavarda, Luiz Felipe, Fernandez, Nicole Suclla, and Scavarda, Annibal José. (2012). Sales and operations planning: A research synthesis. International Journal of Production Economics, 138(1), 1-13.

Thompson, Leigh, and Loewenstein, George. (1992). Egocentric interpretations of fairness and interpersonal conflict. Organizational Behavior and Human Decision Processes, 51(2), 176-197.

Toon, Mark A, Morgan, Robert E, Lindgreen, Adam, Vanhamme, Joëlle, and Hingley, Martin K. (2016). Processes and integration in the interaction of purchasing and marketing: Considering synergy and symbiosis. Industrial Marketing Management, 52, 74-81.

Tuli, Kapil R, Kohli, Ajay K, and Bharadwaj, Sundar G. (2007). Rethinking customer solutions: From product bundles to relational processes. Journal of Marketing, 71(3), $1-17$.

Tuomikangas, Nina, and Kaipia, Riikka. (2014). A coordination framework for sales and operations planning (S\&OP): Synthesis from the literature. International Journal of Production Economics, 154, 243-262.

Turkulainen, Virpi, Kujala, Jaakko, Artto, Karlos, and Levitt, Raymond E. (2013). Organizing in the context of global project-based firm-The case of sales-operations interface. Industrial Marketing Management, 42(2), 223-233.

Virtanen, Tatu., Parvinen, Petri., and Rollins, Minna. (2015). Complexity of sales situation and sales lead performance: An empirical study in a business-to-business company. Industrial Marketing Management, 45(2015), 49-58.

Wagner, Stephan M, Ullrich, Kristoph KR, and Transchel, Sandra. (2014). The game plan for aligning the organization. Business Horizons, 57(2), 189-201. 
Wilson, Timothy L, Boström, Ulf, and Lundin, Rolf. (1999). Communications and expectations in after-sales service provision: Experiences of an international Swedish firm. Industrial Marketing Management, 28(4), 381-394.

Yin, Robert K. (2013). Case study research: Design and methods. Sage publications.

Zackariasson, Peter, and Wilson, Timothy L. (2004). Internetworked after-sales service. Industrial Marketing Management, 33(2), 75-86.

Zarpelon Neto, Germano, Pereira, Giancarlo Medeiros, and Borchardt, Miriam. (2015). What problems manufacturing companies can face when providing services around the world? Journal of Business and Industrial Marketing, 30(5), 461-471. 